\title{
Definitional Skills of Learners with and without Developmental Language Disorder
}

\author{
Ifigeneia Dosi \\ Department of Greek Philology, Democritus University of Thrace, Komotini, Greece \\ http:/ / orcid.org/0000-0003-4911-2049 \\ Zoe Gavriilidou \\ Department of Greek Philology, Democritus University of Thrace, Komotini, Greece \\ http://orcid.org/0000-0002-5975-6852 \\ Chrysoula Dourou \\ Department of Greek Philology, Democritus University of Thrace, Komotini, Greece \\ http://orcid.org/0000-0002-0767-6455
}

\begin{abstract}
Definitions exhibit aspects of mental lexicon organization. Learners with Developmental Language Disorder (DLD) have limited vocabulary knowledge (in breadth and depth) and, thus, less mature definitional skills. Word characteristics affect the definitional skills. This study investigated the definitional skills of learners with and without DLD considering different word characteristics. Moreover, issues like deviant vs. delayed abilities and the link between breadth and depth of vocabulary knowledge are addressed. Thirty-six learners were divided into three groups (a DLD and two control groups [CG] of typically developing learners matched on either age or vocabulary). They were asked to define 16 words. Answers were scored for content and form. Findings revealed that the DLD group scored lower than both CGs in content, while no differences were found in form. Definitions of abstract and compound words were more demanding for all. Correlations between vocabulary and definitional skills were detected only in the agematched CG. From the above, we deduce that DLD learners' definitional skills are deviant. In addition, clinical practice should not look at effects of isolated variables, but rather investigate the interrelation of different parameters. Finally, the link between breadth and depth of vocabulary knowledge may require more time to emerge in DLD learners.
\end{abstract}

Keywords: Developmental Language Disorder; definitional skills; word characteristics; breadth and depth of vocabulary knowledge 


\section{Introduction}

Definitional skills depict mental lexicon organization and depth of vocabulary knowledge. Learners with DLD have reduced breadth (i.e., vocabulary size) and depth of vocabulary knowledge and, thus, they produce informal definitions. An open issue is whether the linguistic abilities of this group are delayed or deviant. Definitional skills are affected by word characteristics; hence, definitions of abstract and compound words are more demanding. This study investigated the definitional skills of learners with and without DLD, taking into account word characteristics, such as concreteness and compoundness. Additionally, issues like deviant vs. delayed abilities and the interrelation between breadth and depth of vocabulary knowledge are discussed.

\subsection{Definitional skills of learners with and without language disorders}

The development of definitional skills provides information about content (meaning) and form (syntactic structure) (Marinellie \& Johnson, 2004). Definitions can be either formal or informal. Regarding content, formal definitions include a superordinate term, and at least one characteristic of the defined object. For instance, "a guitar is a musical instrument that has six strings" (Gutierrez-Cleflen \& DeCurtis, 1999, p. 23). By contrast, informal definitions include either the function of the word (chair: where we sit), or a descriptive term (sing: sounds pretty), or synonyms (bush: is a shrub), or an example (cricket: is a popular sport in England). Regarding form, a formal definition has the following structure " $\mathrm{X}$ is a Y that Z", and it is syntactically more complex (Marinellie \& Johnson, 2004); while informal definitions include noun or verb phrases and predominately main clauses (read: a book; funny: we laugh).

A formal word definition requires word knowledge, use of appropriate semantic features (McGregor et al., 2013), knowledge of form of definitions, as well as metalinguistic abilities. Nevertheless, word knowledge (breadth of vocabulary knowledge) does not, necessarily, imply the ability to define the word (depth of vocabulary knowledge) (McGregor et al., 2013). Schooling seems to be the most critical factor in the development of formal definitions (Schwartz \& Katzir, 2012), because learners are exposed to formal language and definitions at school, whereas the home environment provides more informal language. Therefore, the development of definitional skills is closely related to language development, literacy and academic success. The development of definitions is a gradual process which starts from early childhood and continues through adulthood (Dourou et al., 2020).

Many studies focus on the way typically developing (TD) learners (aged 6 to 12 years) define words, and also on the development of definitions within this age range in terms of both content and form (McGregor et al., 2013; Dourou et al., 2020). Learners initially use informal definitions and they use more formal definitions by the end of the elementary school. Formal definitions require decontextualized language skills. The parallel development of content and form is not a simple process, which probably explains why it takes time for learners to put together the more typical forms of definition (Dourou et al., 2020). 
Examining the content of definitions, younger learners (from 5 to 9 years old) provide definitions based on the most prominent properties of objects (e.g., their functions, use or appearance). Some studies claim that learners from the age of seven use a superordinate term in the definitions of nouns (To et al., 2013). Other studies reported that even at an older age (10-year-old learners), learners' definitions are characterized by self-reference (smart: I am smart) (Dourou, 2019). After the age of eleven, abstract and more formal definitions are more commonly used (Dourou, 2019); the complexity of definitions increases with age, and the strategies used become more mature (Caramelli et al., 2006).

Focusing on the form of definitions, learners, initially, use nominal phrases and later more complex clauses (Friedmann et al., 2011). At the end of elementary school (12 years old) learners have enhanced their metalinguistic abilities and, thus, they are more likely to combine the correct and informative content with the appropriate form.

Studies on definitional skills of learners with Developmental Language Disorder (DLD, previously known as Specific Language Impairment/SLI) are scarce (Marinellie \& Johnson, 2002; Mohammadi et al., 2011; Dosi \& Gavriilidou, 2020). DLD refers to individuals with language deficits in the absence of hearing, intellectual or emotional impairments (Leonard, 2014). An updated definition of the disorder encompasses learners whose non-verbal IQ "is neither impaired enough to justify a diagnosis of intellectual disability nor good enough to be discrepant with overall language level" (Bishop, 2017, p. 679). Research has not given a clear answer yet about the language abilities of learners with DLD. Two general approaches have been proposed: (a) an approach that locates the cause of DLD within the language system, and more specifically, attributes the disorder to deficits in the representations in the grammatical system of the language (Rice et al., 1995), and (b) another approach that attributes the disorder to a deficiency in the non-linguistic processing mechanism (Ullman, 2004). However, none of the proposed theories has explained sufficiently the language abilities of this group. Moreover, the debate about delayed vs. deviant language abilities still continues (Meir \& Armon-Lotem, 2017). The delay hypothesis supports the view that typical acquisitional patterns are followed, albeit with a delay; thus, DLD learners perform like their younger language-matched controls (Rice et al., 1995). Other studies have shown that learners with DLD score lower than their languagematched controls (Briscoe et al., 2001). By contrast, the deviance hypothesis claimed disordered/atypical acquisitional patterns (i.e., quantitative and qualitative differences) that are not detected in younger language-matched TD learners (Meir \& Armon-Lotem, 2017). Language deficits in learners with DLD that persist into adolescence may suggest that the initial delay ultimately becomes a deviance (Conti-Ramsden et al., 2012).

Previous studies on learners with DLD have shown that the word definitions of this group include less information (Marinellie \& Johnson, 2002) than those of other learners. Moreover, they produce predominately informal definitions compared to their age-matched TD learners (Marinellie \& Johnson, 2002), possibly because formal definitions require more abstract thinking and better organization, 
and go beyond the functional use of words (Ponari et al., 2018). McGregor et al. (2013) suggest that learners with DLD have shallower word knowledge than their TD grade-mates, and they face persistent difficulties in word organization and association. Other studies suggest that the delayed production of formal definitions in learners with DLD, is due to differences in lexical and metalinguistic development (Marinellie \& Johnson, 2002). This claim is supported by Krzemien et al. (2021), who found that some aspects of lexical acquisition (i.e., word generalization) were similar to TD age-matched learners when learners were controlled for their vocabulary, which suggests that learners with DLD language abilities are delayed rather than deviant. Mohammadi et al. (2011) noted that the definitional skills of Persian-speaking learners with DLD were weaker due to their language difficulties which prevent the full meaning representation. Adding to the work of previous studies, Dosi (2021) and Dosi and Gavriilidou (2020) have found differences between learners with and without DLD definitional abilities, albeit only in content and not in form. Moreover, they did not find correlations between executive functions (i.e., inhibition, updating, and working memory), vocabulary and definitions in the DLD, while the link was only observed in the TD group. The authors suggested that the development of definitions was driven by different mechanisms in (non-)impaired learners, or the link had not yet emerged due to their delayed abilities.

\subsection{The impact of grammatical categories on the development of definitional skills}

Another important factor to be considered is the grammatical category of the word. Nouns are more easily defined than other grammatical categories, such as verbs or adjectives, not only in content (Dourou, 2019; Gavriilidou, 2015), but also in form (Dourou, 2019; Friedmann et al., 2011). At the age of seven to eight years, learners seem to include superordinate terms in their nominal definitions (Dourou, 2019; To et al., 2013).

Verbs are harder to define because they refer to activities, motion, changes of state, causal relations, or occurrances between objects and acting persons (Gavriilidou, 2015). Furthermore, compared to nouns, verbs demonstrate a less hierarchical nature which inhibits the activation of a class term around which to construct a definition (Gavriilidou, 2015; Johnson \& Anglin, 1995). Marinellie and Chan (2006) claimed that definitions of verbs produced by learners at the age of four often include relationships, associations and synonyms and often are used in infinitive phrases. Similar studies (Dourou, 2019; Gavriilidou, 2015) have found that verbs are predominantly defined based on their function or by an example. With regard to form, learners preferred to define verbs using a phrase or simple clause, and to a lesser extent, using embedded clauses (Dourou, 2019).

Definitions of adjectives are less studied (Dourou, 2019; Gavriilidou, 2015; Marinellie \& Chan, 2006). The definitional skills for adjectives develop much later than the definitional skills for nouns (Johnson \& Anglin, 1995). Learners often use examples, synonyms and associations in definitions of adjectives (Dourou, 2019), while in terms of form they use verb phrases or, to a lesser extent, relative clauses. In the study of Gavriilidou (2015), adjectives were better defined than abstract nouns and verbs, which implies that the semantic characteristics of a word (i.e., 
concrete vs. abstract words) also affect definitional skills indicating that various variables interrelate, that is why they should not be investigated separately. No previous research investigated the effect of the grammatical category on definitions delivered by learners with DLD.

\subsection{The impact of semantic characteristics on the development of definitional skills}

As implied above, semantic characteristics affect both content and form of definitions (Caramelli et al., 2006; Johnson \& Anglin, 1995). Similar to the findings of Gavriilidou (2015) in pre-schoolers, studies in school-aged learners (aged 6-10 years) (Johnson \& Anglin, 1995) have shown that definitions of concrete nouns have been more accurate as a result of connection with other superordinate and subordinate nouns and this can be observed after the age of seven. By contrast, the use of superordinate terms of abstract nouns has not yet been developed in lower elementary school learners (Dourou, 2019). Studies including older individuals (aged 10,14, and 18 years) similarly found that scores on concrete nouns were higher than on abstract nouns (Dourou et al., 2020). More specifically, it was observed that the definitions of concrete nouns were based mainly on their superordinate categories and characteristics, while abstract nouns were only defined in terms of their characteristics. Definitions of abstract nouns seem to improve in late adolescence and in adulthood (Dourou, 2019). The effect of semantic characteristics on definitions produced by learners with DLD has not yet been investigated.

\subsection{The impact of morphological structure on the development of definitional skills}

Another factor that has been less examined, but was found to affect definitional skills is morphological structure of the word (Dourou, 2019). Simple words are defined better, both in content and form, compared to compound words. More specifically, school-aged learners tend to decompose the compound words in parts (cheese pie: cheese and pie), and to use tautologies regardless of the grammatical category of the compound noun. The definitions of compound words improve as learners get older, especially those of abstract compound words that seem to be completed in adulthood (Dourou, 2019). Educational level seems to play a crucial role. The effect of morphological structure in definitions produced by learners with DLD was examined by means of word naming in the study of Grela et al. (2005). The results showed that learners with DLD had difficulty ordering Noun+Noun compounds. Ordering compounds erroneously may occur due to failing to fully comprehend the semantic relationship between the modifier and the head.

\section{Aims and research questions and hypotheses}

From the literature discussed, it is inferred that issues still exist about definitional skills of learners with and without DLD. Addressing these gaps, this study aimed to (a) compare the definitional skills of learners with and without DLD concerning the matter of delayed or deviant abilities, (b) investigate how these skills are affected by less-researched variables such as grammatical categories, semantic characteristics and morphological structure, and, finally, (c) examine the 
relationship between breadth of vocabulary and the development of definitions (i.e., depth of vocabulary).

This study built on the research of Dosi and Gavriilidou (2020) and Dosi (2021), by delving into the definitional skills of school-aged learners with and without DLD by adding an extra vocabulary-matched control group (CG). Three interrelated questions were addressed:

RQ1: Do overall definitional skills differ, in terms of content and form, between learners with and without DLD?

RQ2: Do factors such as grammatical categories, semantic characteristics and morphological structure play a role in the production of word definitions, and which types of definitions are used per group?

RQ3: Do definitional skills (depth of vocabulary knowledge) of different grammatical categories correlate with expressive vocabulary (breadth of vocabulary knowledge)?

The following hypotheses were put forward:

RH1: We expect that the age-matched CG will score better than the DLD group (Dosi \& Gavriilidou, 2020), while the vocabulary-matched CG will exhibit a similar performance than learners with DLD (Rice et al., 1995). Two CGs were included, in order to disentangle language-level issues from agerelated issues.

RH2: We assume that (a) nouns will be defined better compared to adjectives and verbs (Johnson \& Anglin, 1995; Gavriilidou, 2015); (b) concrete words will be defined better in comparison to abstract words (Johnson \& Anglin, 1995; Caramelli et al., 2006); and (c) simple words will be defined better compared to compound words, in which it is expected to find tautologies (Dourou, 2019).

RH3: We expect that the breadth of vocabulary will correlate with the definitional skills (depth of vocabulary knowledge) (McGregor et al., 2013), at least in CGs (Dosi \& Gavriilidou, 2020).

\section{Methods}

\subsection{Participants}

Thirty-six monolingual Greek-speaking learners aged between 5.5-12 years (Mean: 8.1;SD: 1.6) participated in the study. Participants were divided into three groups (the experimental group, and two control groups - the one matched according to chronological age, and the other on vocabulary age).

Two baseline tasks were administered to all participants (Table 1), namely (a) a non-verbal intelligence task (Raven et al., 2008) and (b) an expressive vocabulary task (Vogindroukas et al., 2009), which were normed for three- to ten-year-old Greek-speaking learners. The tasks aimed to ascertain that all participants' general non-verbal intelligence was normal (cut-off point was 85), and to detect their vocabulary knowledge abilities in order to be matched accordingly.

The experimental group (henceforth DLD group) consisted of twelve learners with DLD (age range: 7.3-11.8 years; mean age: 9.1, SD: 1.2), who were recruited 
by Speech and Language Pathologists (SLPs). According to SLP reports, the learners met the following selection criteria in order to be included in the experimental group: absence of auditory or visual problems; no evidence of neurological impairment; absence of disorders in social interaction and communication, such as autism (Leonard, 2014). Based on SLP reports, the nonverbal abilities of the group were within the normal limits for their chronological age (Bishop, 2017), and their verbal abilities (vocabulary and morphosyntax) were at least $2 \mathrm{SD}$ below the expected normative mean of chronologically age-matched peers. Their non-verbal fluid intelligence was also verified by study testing and had to be at least 85 . The participants in this group had been receiving speech and language therapy for at least three years.

For the purposes of this study, two control groups of TD learners were recruited from Greek primary schools. In both cases, TD learners were described by their classroom teachers as using normal language and not having any learning difficulties. In the first Control Group (henceforth CG1), each participant was matched on age to a child from the DLD group. Each age-matched child was up to six months younger/older than the DLD child. CG1 consisted of twelve TD learners of equivalent chronological age (age range 7.2-12 years; mean age 8.5, SD 1.6). The second Control Group (henceforth CG2) consisted of twelve younger TD learners of equivalent vocabulary age as the learners of the DLD group (age range 5.5-7.5 years; mean age 6.6, SD 0.7; based on the categorization of Levy \& Schaeffer, 2003). The expressive vocabulary tasks used information about the lexical age of the children based on their scores; each vocabulary-matched child, thus, was six months younger/older than the equivalent DLD child.

Since the sample was small, non-parametric criteria (Kruskal-Wallis test or Mann Whitney test) were applied. Age differences were found among the groups $(\mathrm{H}(2)=$ $18.575, \mathrm{p}<.001)$. Further analyses showed that CG2 was significantly younger that the DLD group and CG1 $(U=1.000, p<.001$ and $U=18.500, p=.001)$; while no difference was found between the DLD and CG1 groups $(U=48.500, p=.912)$.

Table 1: Participants' profiles

\begin{tabular}{|c|c|c|c|c|}
\hline Group & $\mathbf{N}$ & $\begin{array}{c}\text { Chronological } \\
\text { age } \\
\text { (years; } \text { SD) }\end{array}$ & $\begin{array}{c}\text { Expressive } \\
\text { vocabulary scores } \\
\text { (vocabulary age; SD) }\end{array}$ & $\begin{array}{c}\text { Non-verbal } \\
\text { intelligence } \\
\text { (standard score; } \text { SD) }\end{array}$ \\
\hline DLD & 12 & $9 ; 1(1.2)$ & $7.2(1.7)$ & $98.5(4.5)$ \\
\hline CG1 & 12 & $8 ; 5(1.6)$ & $10(1.6)$ & $102.6(3.4)$ \\
\hline CG2 & 12 & $6 ; 6(0.7)$ & $6.9(0.7)$ & $87.8(2.8)$ \\
\hline
\end{tabular}

The results showed that the groups differed in terms of expressive vocabulary skills $(H(2)=17.952, p<.001)$. Mann Whitney tests among the groups showed that CG1 outperformed both DLD and CG2 $(U=14.500, p<.001$; and $U=4.500, p<.001$, respectively), while no differences were found between DLD and CG2 ( $U=63.000$, $p=.630)$.

Regarding non-verbal intelligence, differences were observed among the groups $(H(2)=23.507, p<.001)$. Further tests between the groups indicated that the DLD 
and the CG1 did not differ $(U=52.000, p=.266)$, while the CG2 differed from the two other groups ( $U=1.000, p<.001$, for both comparisons).

The participants were also matched based on gender and socio-economic background. Informed consent in writing was obtained beforehand from parents/guardians of all learners included in the study. All procedures performed in the study were in accordance with the ethical standards of the institutional Ethics Committee of Democritus University of Thrace (60589/2111/31-8-2018) and the national research committee.

\subsection{Research Instruments}

Apart from the baseline tasks, all participants were tested by means of an elicited production task investigating definitional skills. In order to achieve comparability of the results, the definition task and the methodology adopted were similar to those used in the study of Marinellie \& Johnson $(2002,2004)$ adapted in Greek by Gavriilidou (2015) and applied in Dourou (2019), Dourou et al. (2020), Dosi and Gavriilidou (2020) and Dosi (2021). The task included 16 items: eight nouns (concrete vs. abstract, simple vs. compound), four adjectives (simple vs. compound) and four verbs (simple vs. compound), as depicted in Table 2. Ten of the words were chosen from school coursebooks and the other six from the study of Gavriilidou (2015). In the study of Gavriilidou (2015), teachers identified, by means of a questionnaire, 500 out of 800 more frequent words in everyday class interactions and classroom activities. The criteria of item selection were high word frequency, age appropriateness, together with compliance with the criteria of grammatical category, morphological structure, and semantic characteristics.

Table 2: Definitional task items grouped per grammatical categories

\begin{tabular}{|c|c|c|c|}
\hline $\begin{array}{c}\text { Grammatical } \\
\text { categories }\end{array}$ & $\begin{array}{l}\text { Morphological } \\
\text { structure }\end{array}$ & $\begin{array}{c}\text { Semantic } \\
\text { characteristics }\end{array}$ & Task items \\
\hline \multirow[t]{8}{*}{ Nouns } & \multirow[t]{4}{*}{ simple } & \multirow[t]{2}{*}{ concrete } & milo 'apple' \\
\hline & & & poðilato 'bike' \\
\hline & & \multirow[t]{2}{*}{ abstract } & taksiði 'trip' \\
\hline & & & erotisi 'question' \\
\hline & \multirow[t]{4}{*}{ compound } & \multirow[t]{2}{*}{ concrete } & tiropita 'cheese pie' \\
\hline & & & maçeropiruno 'cutlery' \\
\hline & & \multirow[t]{2}{*}{ abstract } & iKovasilema 'sunset' \\
\hline & & & makrozoia 'longevity' \\
\hline \multirow[t]{4}{*}{ Verbs } & \multirow{2}{*}{\multicolumn{2}{|c|}{ simple }} & Sjavazo 'read' \\
\hline & & & xorevo 'dance' \\
\hline & \multirow{2}{*}{\multicolumn{2}{|c|}{ compound }} & aniroklino 'open and close' \\
\hline & & & sirotraruðo 'croon' \\
\hline \multirow[t]{4}{*}{ Adjectives } & \multirow{2}{*}{\multicolumn{2}{|c|}{ simple }} & astios 'funny' \\
\hline & & & eksipnos 'smart' \\
\hline & \multirow{2}{*}{\multicolumn{2}{|c|}{ compound }} & aspromavros 'black and white' \\
\hline & & & rlikoksinos 'sweet and sour' \\
\hline
\end{tabular}


A warm-up session preceded the session, where the examiner gave an example of a formal definition and requested the participant afterwards to define a word. If the participant used an informal definition, the examiner gave corrective feedback by providing a formal definition of the word. During the main session the examiner just asked the participant, "What does X mean?" without showing any picture or object, and without any further prompt. Participants' responses were audio-taped and transcribed afterwards.

The coding was based on the work of Marinellie and Johnson (2002, 2004). Participants' answers were scored for both content and form on a five-point scale. For content-scoring, if the participant pointed at the object or used gestures in describing the word, they received 0 points. In accordance with previous literature, as Low-level responses (Table 3) were deemed Function, Descriptive, Concrete Example, and Association (1 point). As Mid-level responses (Table 3) were deemed Class-Nonspecific, Class-Specific, and Synonym (2-3 points), while High-level responses included Combination (any combination of Function, Descriptive, Concrete, and Association, or Class-Nonspecific), and Formal (combination of Class-Specific or Synonym and at least one specifying attribute such as Function, Concrete, Description, Example, Synonym; received 4-5 points). Examples and marking per category are presented in Table 3 below.

Table 3: Examples of scoring the content of definitional types

\begin{tabular}{|c|c|c|c|c|c|c|c|}
\hline $\begin{array}{l}\text { Content } \\
\text { category }\end{array}$ & $\begin{array}{l}\text { Simple } \\
\text { word } \\
\text { (ques- } \\
\text { tion) }\end{array}$ & \begin{tabular}{|c|} 
Compound \\
word (cheese- \\
pie)
\end{tabular} & $\begin{array}{l}\text { Concrete } \\
\text { noun } \\
\text { (apple) }\end{array}$ & $\begin{array}{c}\text { Abstract } \\
\text { noun (trip) }\end{array}$ & $\begin{array}{l}\text { Adjective } \\
\text { (funny) }\end{array}$ & Verb (read) & Points \\
\hline Nonverbal & \multicolumn{6}{|c|}{ (They show the thing or they use gestures) } & 0 \\
\hline Function & $\begin{array}{l}\text { We ask } \\
\text { some- } \\
\text { thing }\end{array}$ & $\begin{array}{c}\text { I eat a cheese- } \\
\text { pie }\end{array}$ & $\begin{array}{l}\text { I eat an } \\
\text { apple }\end{array}$ & $\begin{array}{l}\text { When we go } \\
\text { somewhere }\end{array}$ & $\begin{array}{c}\text { When we } \\
\text { are doing } \\
\text { funny things }\end{array}$ & $\begin{array}{l}\text { I read a } \\
\text { fairytale }\end{array}$ & 1 \\
\hline $\begin{array}{l}\text { Descrip- } \\
\text { tive }\end{array}$ & $\begin{array}{c}\text { It has a } \\
\text { question } \\
\text { mark }\end{array}$ & $\begin{array}{c}\text { It's triangular } \\
\text { and has cheese } \\
\text { inside }\end{array}$ & $\begin{array}{l}\text { Something } \\
\text { that we eat }\end{array}$ & $\begin{array}{l}\text { When we go } \\
\text { on vacation }\end{array}$ & $\begin{array}{c}\text { Somebody } \\
\text { does funny } \\
\text { things and } \\
\text { we laugh }\end{array}$ & \begin{tabular}{|c|} 
When you \\
open a book \\
and you \\
learn \\
something
\end{tabular} & 1 \\
\hline $\begin{array}{l}\text { Concrete } \\
\text { example }\end{array}$ & $\begin{array}{c}\text { "How are } \\
\text { you?" }\end{array}$ & $\begin{array}{l}\text { Grandma's } \\
\text { cheese pie }\end{array}$ & $\begin{array}{c}\text { It's an apple } \\
\text { on the } \\
\text { backside of } \\
\text { my phone }\end{array}$ & $\begin{array}{c}\text { I go with } \\
\text { mummy and } \\
\text { daddy }\end{array}$ & $\begin{array}{l}\text { My daddy } \\
\text { says jokes }\end{array}$ & $\begin{array}{c}\text { I read every } \\
\text { day for the } \\
\text { school }\end{array}$ & 1 \\
\hline $\begin{array}{c}\text { Associa- } \\
\text { tion }\end{array}$ & Answer & school & juicy & airplane & jokes & a book & 1 \\
\hline $\begin{array}{l}\text { Class non- } \\
\text { specific }\end{array}$ & $\begin{array}{l}\text { It's a } \\
\text { word }\end{array}$ & cheese & food & it's a route & $\begin{array}{l}\text { somebody } \\
\text { can be }\end{array}$ & $\begin{array}{c}\text { I see letters } \\
\text { and say } \\
\text { them aloud }\end{array}$ & 2 \\
\hline $\begin{array}{c}\text { Class } \\
\text { specific or } \\
\text { Synonym }\end{array}$ & problem & breakfast & fruit & holiday & amusing & to study & 3 \\
\hline
\end{tabular}




\begin{tabular}{|c|c|c|c|c|c|c|c|}
\hline $\begin{array}{l}\text { Combina- } \\
\text { tion }\end{array}$ & $\begin{array}{l}\text { A phrase } \\
\text { with a } \\
\text { question } \\
\text { mark at } \\
\text { the end }\end{array}$ & $\begin{array}{c}\text { a food that has } \\
\text { cheese }\end{array}$ & $\begin{array}{c}\text { a fruit that is } \\
\text { red }\end{array}$ & $\begin{array}{c}\text { when we } \\
\text { visit a } \\
\text { country/city } \\
\text { /island }\end{array}$ & $\begin{array}{c}\text { someone } \\
\text { who makes } \\
\text { us laugh } \\
\text { and has fun }\end{array}$ & $\begin{array}{c}\text { when I read } \\
\text { words aloud } \\
\text { and I use a } \\
\text { book }\end{array}$ & 4 \\
\hline Formal & $\begin{array}{c}\text { It's a } \\
\text { phrase } \\
\text { that asks } \\
\text { for } \\
\text { answers }\end{array}$ & $\begin{array}{l}\text { A kind of pie } \\
\text { that has cheese } \\
\text { inside }\end{array}$ & $\begin{array}{c}\text { It is a fruit } \\
\text { that we bite, } \\
\text { and it has } \\
\text { seeds }\end{array}$ & $\begin{array}{c}\text { When we go } \\
\text { to another } \\
\text { place, to have } \\
\text { fun, with } \\
\text { different } \\
\text { means of } \\
\text { transport }\end{array}$ & $\begin{array}{l}\text { A characte- } \\
\text { ristic of } \\
\text { somebody } \\
\text { who has the } \\
\text { sense of } \\
\text { humour and } \\
\text { makes } \\
\text { people } \\
\text { laugh }\end{array}$ & $\begin{array}{c}\text { An action } \\
\text { that requires } \\
\text { looking at } \\
\text { words and } \\
\text { under- } \\
\text { standing } \\
\text { their } \\
\text { meanings }\end{array}$ & 5 \\
\hline
\end{tabular}

In form-scoring, a similar five-point scale-coding was followed: participants received 0 points if they pointed to the object or if they described it non-verbally (Table 4). As Low-level responses (Table 4) were considered the use of One Word (but not the superordinate category) and a determiner (1 point). As Mid-level responses were deemed a Verb Phrase and the words "something/thing" along with a referential phrase (2-3 points). In High-level responses (4-5 points; Table 4 ) were included, Partial formal definitions, giving the superordinate category or an infinitive or verb phrase; in addition, formal definitions were included. Formal definitions contained the Partial formal + a second infinitive or a nonfinite clause or a finite adverbial clause, or a prepositional phrase. 
Table 4: Examples of scoring the form of definitional types

\begin{tabular}{|c|c|c|c|c|c|c|c|}
\hline Form category & $\begin{array}{l}\text { Simple word } \\
\text { (question) }\end{array}$ & $\begin{array}{l}\text { Compound word } \\
\text { (cheese-pie) }\end{array}$ & $\begin{array}{l}\text { Concrete } \\
\text { noun } \\
\text { (apple) }\end{array}$ & Abstract noun (trip) & Adjective (funny) & Verb (read) & Points \\
\hline Non-verbal & \multicolumn{6}{|c|}{ (They show the thing, or they use gestures) } & 0 \\
\hline $\begin{array}{c}\text { One word } \\
(+ \text { determiner })\end{array}$ & a word & cheese & red & vacation & laugh & book & 1 \\
\hline Verb phrase & $\begin{array}{c}\text { we ask } \\
\text { something }\end{array}$ & I eat it every day & we eat it & $\begin{array}{l}\text { we go with mom and } \\
\text { dad }\end{array}$ & we mock & I read a text & 2 \\
\hline $\begin{array}{l}\text { Transitional } \\
\text { ("thing" + } \\
\text { referential } \\
\text { sentence) }\end{array}$ & $\begin{array}{l}\text { something that } \\
\text { asks for } \\
\text { answers }\end{array}$ & $\begin{array}{l}\text { something that has } \\
\text { cheese inside }\end{array}$ & $\begin{array}{l}\text { something } \\
\text { that we eat }\end{array}$ & $\begin{array}{l}\text { something that helps } \\
\text { us to relax }\end{array}$ & $\begin{array}{l}\text { something that has } \\
\text { humour }\end{array}$ & $\begin{array}{l}\text { something that I } \\
\text { do using a book }\end{array}$ & 3 \\
\hline $\begin{array}{l}\text { Partially formal } \\
\text { definitions } \\
\text { (superordinate } \\
\text { category) }\end{array}$ & $\begin{array}{c}\text { a phrase that } \\
\text { has a question } \\
\text { mark }\end{array}$ & a pie that has cheese & $\begin{array}{l}\text { a fruit that } \\
\text { has seeds }\end{array}$ & $\begin{array}{l}\text { a place that we go for } \\
\text { vacation }\end{array}$ & $\begin{array}{c}\text { a characteristic of } \\
\text { somebody who makes } \\
\text { jokes }\end{array}$ & $\begin{array}{l}\text { an action that } \\
\text { requires the study } \\
\text { of a text }\end{array}$ & 4 \\
\hline $\begin{array}{c}\text { Formal } \\
\text { definitions }\end{array}$ & $\begin{array}{l}\text { a phrase that } \\
\text { asks for } \\
\text { answers or } \\
\text { information }\end{array}$ & $\begin{array}{l}\text { a kind of pie that } \\
\text { includes cheese and } \\
\text { we eat it for snack }\end{array}$ & $\begin{array}{l}\text { a fruit that } \\
\text { is round } \\
\text { and red } \\
\text { and it has } \\
\text { seeds }\end{array}$ & $\begin{array}{l}\text { a place to which we } \\
\text { go for pleasure with } \\
\text { different means of } \\
\text { transportation }\end{array}$ & $\begin{array}{l}\text { a characteristic of } \\
\text { somebody or } \\
\text { something that } \\
\text { entertains us and } \\
\text { makes us laugh }\end{array}$ & $\begin{array}{l}\text { an action that } \\
\text { requires going } \\
\text { through a text } \\
\text { recognizing the } \\
\text { written symbols } \\
\text { that it is } \\
\text { composed of }\end{array}$ & 5 \\
\hline
\end{tabular}


In either content or form, the highest possible total score for all categories (nouns, verbs, adjectives) was 80 points (16 words per participant with the maximum of 5 points per word). The results will be presented in percentages.

\subsection{Reliability}

Inter-judge reliability of content coding was evaluated for all responses given by 36 subjects (in total 576 definitions). Any response coded identically by two independent evaluators was considered an agreement. A double-blind marking was followed. Identically coded responses were considered an agreement. The final percentage of agreement was determined by dividing the number of responses coded identically by the total number of coded definitions. The interjudge agreement for content was $89.1 \%$. Inter-judge reliability of form coding was evaluated in a similar way and the agreement was $90 \%$. To check the reliability of the task a Cronbach's Alpha coefficient was calculated. Cronbach's Alpha coefficient for the overall instrument was .795, suggesting a high degree of internal consistency.

\subsection{Data analysis}

To investigate our first and second hypotheses, we performed non-parametric tests (Kruskal-Wallis tests or Mann Whitney tests), since our sample was small. Finally, to test our last research hypothesis we run bivariate correlations between vocabulary scores and the overall scores on content and form, and the scores per grammatical category (nouns, verbs and adjectives), and for each group separately.

\section{Results}

\subsection{Overall definitional skills}

For content, the three groups used more informal definitions, as Figure 1 illustrates. Differences among the groups were detected only in content $(H(2)=$ $18.093, p<.001)$ and not in form $(H(2)=2.185, p=.335)$. Mann Whitney test analysis between the groups showed that in the content the DLD group used more informal definitions than the other two control groups $(U=1.000, p<.001$, for both comparisons), while no differences were attested between the two control groups $(U=52.000, p=.226)$. 


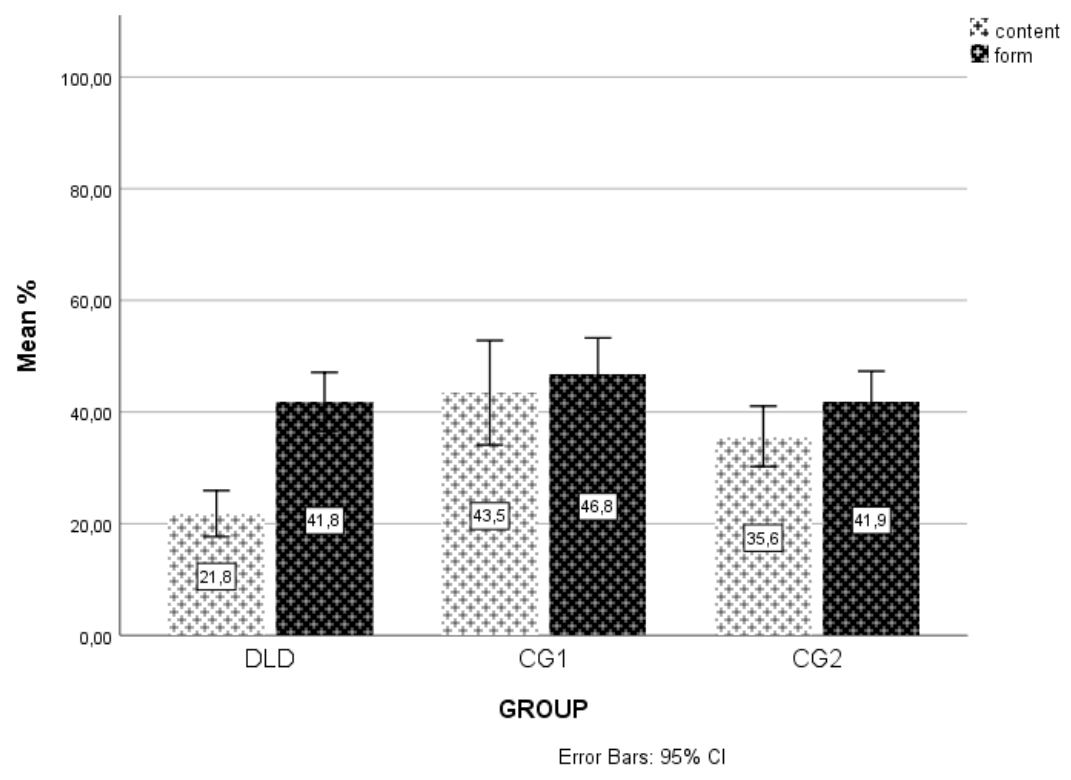

Figure 1: Groups' overall scores for content and form

\subsection{Effects of word characteristics on definitional skills}

\subsubsection{The effect of grammatical categories}

Scores in the grammatical categories (Figure 2) illustrated that in content for nouns the DLD group produced more informal definitions (25.9\%) than the other two control groups (CG1: $52.4 \%$ and CG2: $44.5 \%$; CG1: $U=14.000, p=.001$; CG2: $U=20.000, p=.002)$, while no differences were found between the two control groups $(U=53.500, p=.291)$. The picture is similar for verbs, where informal definitions were given by all groups but the DLD group that also gave some nonverbal responses (17.1\%) compared to the two control groups (CG1: 27.7\%; CG2: $24.2 \% ; U=36.500, p=.039$, for both comparisons). The two control groups did not differ $(U=71.000, p=.977)$. For adjectives, the DLD group and the CG2 predominately used informal definitions $(17.9 \%$ and $29.8 \%$, respectively). Nevertheless, the DLD group also provided some non-verbal responses, compared to the CG2; hence the CG2 outperformed the DLD group ( $U=27.500$, $p=.008)$. The CG1 used more formal definitions than the other two groups (41.3\%; DLD: $U=1.000, p<.001$; CG2: $U=33.500, p=.024)$. By contrast, in form, the scores indicated that mid-level responses were used and no statistical differences were attested between the groups in both categories (nouns: $H(2)=2.424, p=.298$; verbs: $H(2)=3.035, p=.219$; adjectives: $H(2)=1.162, p=.559)$. 


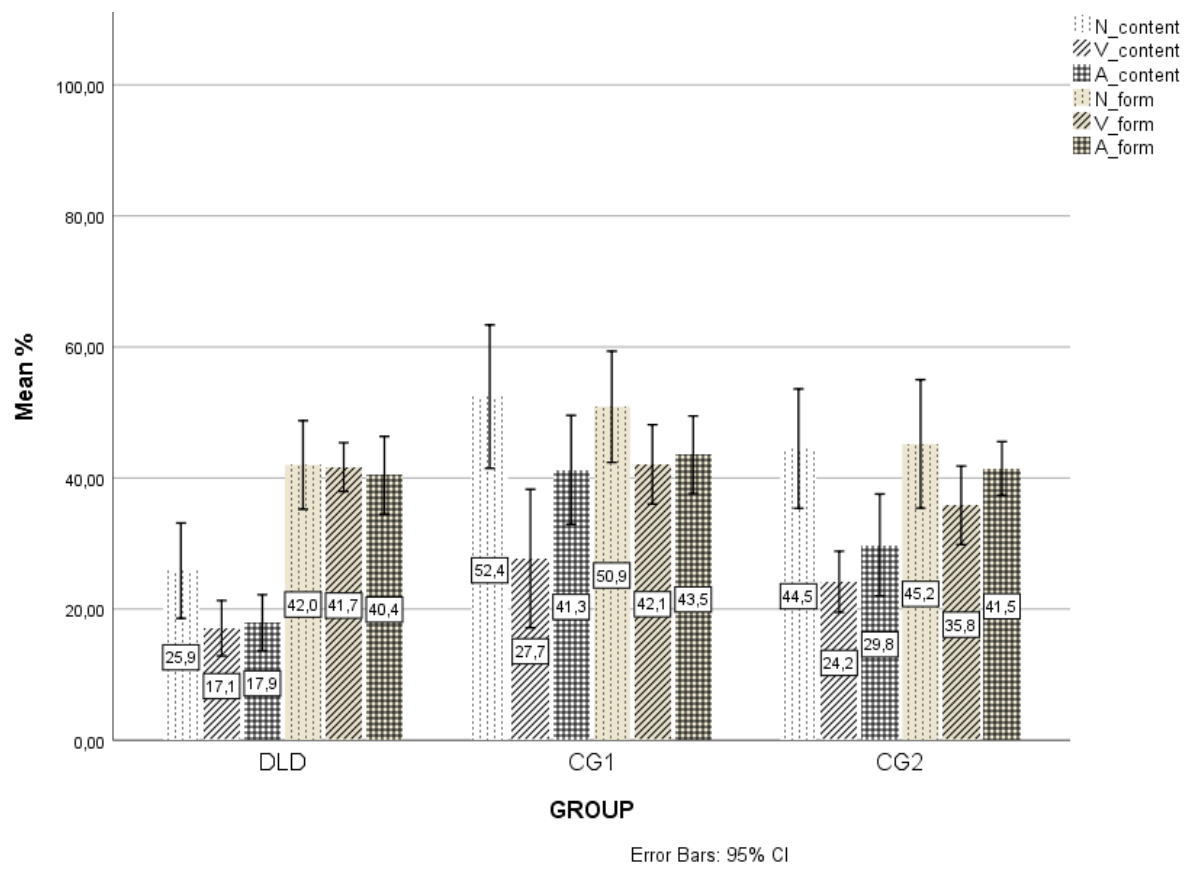

Figure 2: Groups' scores in content and form regarding grammatical categories

\subsubsection{The effect of semantic characteristics}

In content, statistical differences were found only between the CG1 and the DLD group in concrete nouns, where the latter group produced more formal definitions than the former group $(37.9 \%$ vs. $60.6 \%$; $U=31.000, p=.017)$; while no other group differences were noticed $(60.6 \%$ vs. $52.5 \%$; $C G 1$ vs. CG2: $U=57.500$, $p=.410$; DLD vs. CG2: $U=40.000, p=.068)$. Abstract nouns were found to be more challenging for all groups, but particularly for the DLD group (13.8\%), which provided more non-verbal responses than the other two control groups which gave informal definitions (CG1: $U=6.000, p<.001$; CG2: $U=12.000, p<.001$ ). The two control groups did not differ (44.2\% vs. $36 \%$; $U=52.500, p=.266)$. In form, no differences were attested between the groups - neither in concrete $(H(2)=.144, p=$ .930) nor in abstract words $(H(2)=5.847, p=.054)$. 


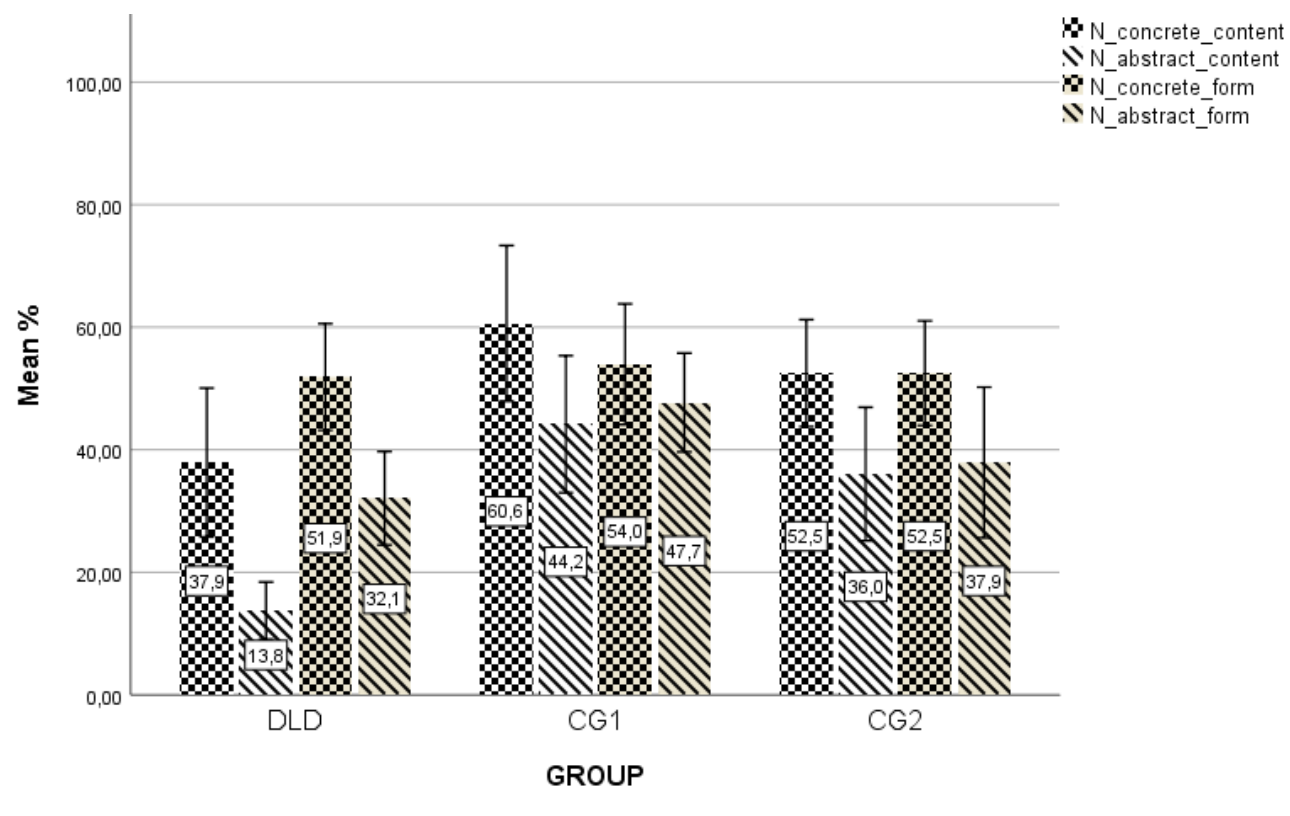

Error Bars: $95 \% \mathrm{Cl}$

Figure 3: Groups' scores in content and form regarding semantic categories

\subsubsection{The effect of morphological structure}

In content, the CG1 gave more formal definitions in simple words $(51.6 \%)$ than the two other groups (DLD group: 24.9\%, $U=7.000, p<.001$; CG2: $37.5 \%, U=$ 27.000, $p=.008$ ), and the CG2 produced more formal definitions than the DLD group $(U=22.500, p=.003)$. Compound words were challenging for all groups, but particularly for the DLD group (13.7\%). Most of the participants gave informal definitions; thus, the two control groups did not differ $(U=71.000, p=.977)$. The DLD group either gave informal definitions or did not give any response (CG1: $U=16.500, p=.001 ; \mathrm{CG} 2: U=11.000, p<.001)$. In form, like content, the CG1 gave more formal definitions (57.3\%) in simple words than the two other groups (DLD group: $46.7 \%, U=36.000, p=.039$; CG2: $44.7 \%, U=22.500, p=.003$ ); however, the DLD group and the CG2 performed similarly in this category $(U=55.000, p=.347$ ). In form of compound word definitions, no differences were found between the groups $(H(2)=.187, p=.911)$. 


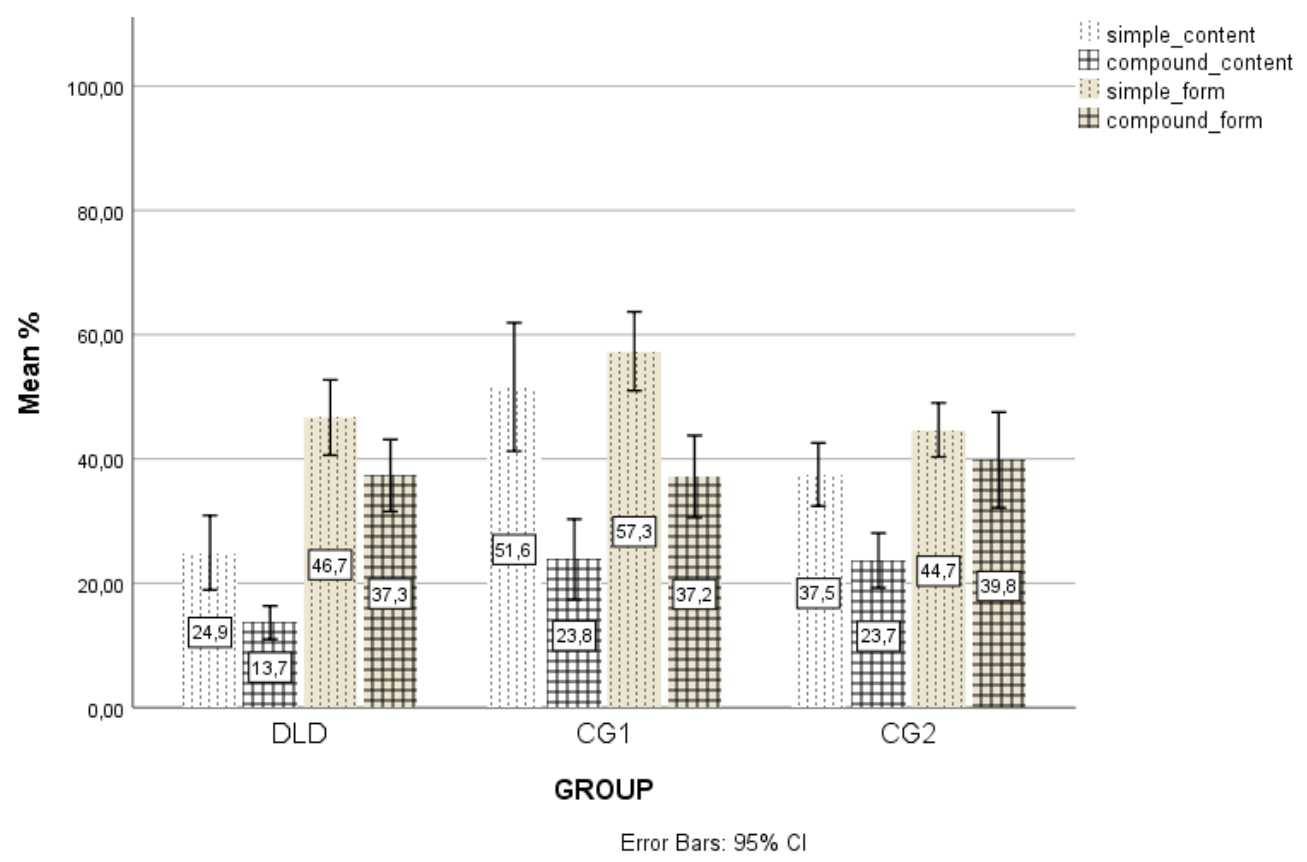

Figure 4: Groups' overall scores in content and form regarding morphological structure

4.2.4. Definitional types per grammatical categories, semantic characteristics and morphological structure

Definitional types of three groups used in terms of content are summarized in Table 5. As the table indicates, most of the participants, regardless of the group, provided low-level responses (i.e., functional definitions, examples, descriptive answers), with the sole exceptions of CG2, who produced mid-level responses (i.e., class specific definitions) for concrete nouns, and CG1, who gave high-level responses (i.e., combination) for simple nouns (both concrete and abstract) and simple adjectives. By contrast, for compound abstract nouns all groups used nonverbal responses. Interestingly, in most of the cases in compound abstract nouns the CG2 and some learners of the DLD group did not know or did not give a response or tried to describe the word non-verbally.

In form (Table 6), all groups preferred to define words using mid-level responses, by using verb phrases. A different performance was detected in CG1, who used a transitional form "something/thing" + referential sentence for simple adjectives, and in CG2, who used high-level responses (partially formal definitions) for concrete nouns.

We should note, at this point, that older TD learners used more mature definitions both in content and in form, particularly for nouns, while age-matched DLD learners still used more informal but informative definitions. 
Table 5: Definitional types in different categories in content per group ${ }^{1}$

\begin{tabular}{|c|c|c|c|c|c|c|c|c|c|c|c|}
\hline & & & & $\begin{array}{l}\text { NR/ } \\
\text { IDK }^{2}\end{array}$ & $\begin{array}{c}\text { Non- } \\
\text { verbal }\end{array}$ & $\begin{array}{l}\text { Function/Descrip } \\
\text {-tive/Concrete }\end{array}$ & $\begin{array}{l}\text { Class non- } \\
\text { specific }\end{array}$ & $\begin{array}{c}\text { Class } \\
\text { specific }\end{array}$ & Combination & Formal & $\begin{array}{c}\text { Total } \\
\text { answers }\end{array}$ \\
\hline \multirow{12}{*}{$\stackrel{\mathscr{Z}}{\mathscr{Z}}$} & \multirow{6}{*}{ 常 } & \multirow[t]{3}{*}{ concrete } & $D L D$ & 0 & 1 & 12 & 1 & 5 & 5 & 0 & 24 \\
\hline & & & CG1 & 0 & 0 & 6 & 2 & 0 & 13 & 3 & 24 \\
\hline & & & CG2 & 0 & 0 & 2 & 4 & 10 & 7 & 1 & 24 \\
\hline & & \multirow[t]{3}{*}{ abstract } & $D L D$ & 0 & 2 & 14 & 4 & 2 & 2 & 0 & 24 \\
\hline & & & CG1 & 0 & 0 & 10 & 0 & 2 & 12 & 0 & 24 \\
\hline & & & CG2 & 0 & 1 & 18 & 0 & 2 & 3 & 0 & 24 \\
\hline & \multirow{6}{*}{ 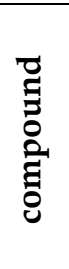 } & \multirow[t]{3}{*}{ concrete } & $D L D$ & 0 & 2 & 13 & 3 & 2 & 4 & 0 & 24 \\
\hline & & & CG1 & 0 & 0 & 8 & 1 & 7 & 8 & 0 & 24 \\
\hline & & & CG2 & 0 & 0 & 12 & 4 & 4 & 3 & 1 & 24 \\
\hline & & \multirow[t]{3}{*}{ abstract } & $D L D$ & 8 & 10 & 4 & 2 & 0 & 0 & 0 & 24 \\
\hline & & & CG1 & 3 & 6 & 5 & 1 & 2 & 6 & 1 & 24 \\
\hline & & & CG2 & 9 & 1 & 4 & 1 & 3 & 4 & 2 & 24 \\
\hline \multirow{6}{*}{ 䓪 } & \multirow{3}{*}{\multicolumn{2}{|c|}{ simple }} & DLD & 1 & 5 & 17 & 1 & 0 & 0 & 0 & 24 \\
\hline & & & CG1 & 0 & 0 & 18 & 0 & 1 & 4 & 1 & 24 \\
\hline & & & CG2 & 1 & 0 & 23 & 0 & 0 & 0 & 0 & 24 \\
\hline & \multirow{3}{*}{\multicolumn{2}{|c|}{ compound }} & $D L D$ & 0 & 2 & 22 & 0 & 0 & 0 & 0 & 24 \\
\hline & & & CG1 & 0 & 0 & 23 & 0 & 0 & 1 & 0 & 24 \\
\hline & & & CG2 & 1 & 0 & 20 & 0 & 1 & 2 & 0 & 24 \\
\hline \multirow{6}{*}{ 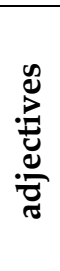 } & \multirow{3}{*}{\multicolumn{2}{|c|}{ simple }} & DLD & 0 & 8 & 13 & 0 & 1 & 2 & 0 & 24 \\
\hline & & & CG1 & 0 & 0 & 3 & 6 & 4 & 11 & 0 & 24 \\
\hline & & & CG2 & 1 & 1 & 13 & 0 & 3 & 6 & 0 & 24 \\
\hline & \multirow{3}{*}{\multicolumn{2}{|c|}{ compound }} & $D L D$ & 2 & 4 & 16 & 2 & 0 & 0 & 0 & 24 \\
\hline & & & CG1 & 1 & 0 & 21 & 0 & 0 & 2 & 0 & 24 \\
\hline & & & CG2 & 2 & 1 & 19 & 2 & 0 & 0 & 0 & 24 \\
\hline \multicolumn{4}{|c|}{ Total } & 29 & 44 & 316 & 34 & 49 & 95 & 9 & 576 \\
\hline \multicolumn{4}{|c|}{$\%$} & 5.0 & 7.6 & 54.9 & 5.9 & 8.5 & 16.5 & 1.6 & 100.0 \\
\hline
\end{tabular}

${ }^{1}$ The sum and the most frequent answers are in bold (in both Tables 5 and 6).

${ }^{2}$ No response (NR) or answered I don't know (IDK)

http://ijlter.org/index.php/ijlter 
Table 6: Definitional types in different categories in form per group

\begin{tabular}{|c|c|c|c|c|c|c|c|c|c|c|c|}
\hline & & & & $\begin{array}{l}\text { NR/ } \\
\text { IDK }\end{array}$ & Non-verbal & $\begin{array}{c}\text { One } \\
\text { word }\end{array}$ & $\begin{array}{c}\text { Verb } \\
\text { phrase }\end{array}$ & $\begin{array}{l}\text { "thing"+ } \\
\text { referential } \\
\text { sentence }\end{array}$ & $\begin{array}{l}\text { Partially } \\
\text { formal }\end{array}$ & Formal & Total answers \\
\hline \multirow{12}{*}{ 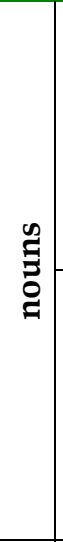 } & \multirow{6}{*}{ 常 } & \multirow[t]{3}{*}{ concrete } & $D L D$ & 0 & 1 & 3 & 8 & 7 & 3 & 2 & 24 \\
\hline & & & CG1 & 0 & 0 & 4 & 3 & 7 & 7 & 3 & 24 \\
\hline & & & CG2 & 0 & 0 & 4 & 2 & 6 & 11 & 1 & 24 \\
\hline & & \multirow[t]{3}{*}{ abstract } & DLD & 0 & 2 & 2 & 17 & 3 & 0 & 0 & 24 \\
\hline & & & CG1 & 0 & 0 & 1 & 8 & 9 & 6 & 0 & 24 \\
\hline & & & CG2 & 0 & 1 & 8 & 11 & 3 & 1 & 0 & 24 \\
\hline & \multirow{6}{*}{ 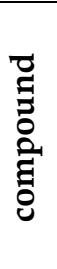 } & \multirow[t]{3}{*}{ concrete } & $D L D$ & 0 & 2 & 6 & 8 & 5 & 2 & 1 & 24 \\
\hline & & & CG1 & 0 & 0 & 4 & 12 & 5 & 3 & 0 & 24 \\
\hline & & & CG2 & 0 & 0 & 7 & 8 & 4 & 4 & 1 & 24 \\
\hline & & \multirow[t]{3}{*}{ abstract } & $D L D$ & 8 & 10 & 0 & 3 & 3 & 0 & 0 & 24 \\
\hline & & & CG1 & 3 & 6 & 0 & 7 & 2 & 5 & 1 & 24 \\
\hline & & & CG2 & 9 & 1 & 5 & 4 & 0 & 2 & 3 & 24 \\
\hline \multirow{6}{*}{ 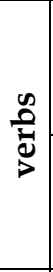 } & \multirow{3}{*}{\multicolumn{2}{|c|}{ simple }} & DLD & 1 & 5 & 3 & 11 & 4 & 0 & 0 & 24 \\
\hline & & & CG1 & 0 & 0 & 3 & 16 & 0 & 5 & 0 & 24 \\
\hline & & & CG2 & 1 & 0 & 5 & 17 & 1 & 0 & 0 & 24 \\
\hline & \multirow{3}{*}{\multicolumn{2}{|c|}{ compound }} & DLD & 0 & 2 & 2 & 16 & 4 & 0 & 0 & 24 \\
\hline & & & CG1 & 0 & 0 & 2 & 21 & 1 & 0 & 0 & 24 \\
\hline & & & CG2 & 1 & 0 & 2 & 20 & 0 & 1 & 0 & 24 \\
\hline \multirow{6}{*}{ 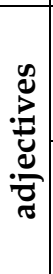 } & \multirow{3}{*}{\multicolumn{2}{|c|}{ simple }} & $D L D$ & 0 & 8 & 0 & 11 & 5 & 0 & 0 & 24 \\
\hline & & & CG1 & 0 & 0 & 1 & 5 & 14 & 4 & 0 & 24 \\
\hline & & & CG2 & 1 & 1 & 1 & 13 & 8 & 0 & 0 & 24 \\
\hline & \multirow{3}{*}{\multicolumn{2}{|c|}{ compound }} & DLD & 2 & 4 & 5 & 10 & 3 & 0 & 0 & 24 \\
\hline & & & CG1 & 1 & 0 & 13 & 7 & 3 & 0 & 0 & 24 \\
\hline & & & CG2 & 2 & 1 & 3 & 17 & 1 & 0 & 0 & 24 \\
\hline \multicolumn{4}{|c|}{ Total } & 29 & 44 & 84 & 255 & 98 & 54 & 12 & 576 \\
\hline \multicolumn{4}{|c|}{$\%$} & 5.0 & 7.6 & 14.6 & 44.3 & $\mathbf{1 7 . 0}$ & 9.4 & 2.1 & 100.0 \\
\hline
\end{tabular}




\subsection{Vocabulary use and definitional skills}

Bivariate correlations were performed for each group separately, in order to observe possible associations. In the DLD and CG2 groups no correlations were found between the scores for vocabulary and the definitions of the different grammatical categories (nouns, verbs, adjectives), neither in content nor in form. Correlations were detected only in CG1 in overall scores in content and form $(r(12)=.734, p=.007 ; r(12)=.803, p=.002$; respectively), in nouns (in both content: $r(12)=.836, p=.001$ and form: $r(12)=.834, p=.001)$ and in adjectives, only in content $(r(12)=.675, p=.016)$.

\section{Discussion}

In this study we investigated (a) the definitional skills of learners with and without DLD, addressing the issue of delayed or deviant abilities; (b) the impact of grammatical categories, semantic characteristics and morphological structure on the development of definitions, and, finally, (c) the association between the breadth and depth of vocabulary knowledge.

\subsection{Overall definitional skills}

Our findings provide a mixed picture about the definitional skills of DLD learners. Our first hypothesis was partially confirmed. Learners with DLD used more informal definitions (cf. Marinellie \& Johnson, 2002; Dosi, 2021) than both control groups in terms of the content of definitions (cf. Briscoe et al., 2001). However, in respect of form all three groups performed similarly (cf. Dosi \& Gavriilidou, 2020; Dosi, 2021); in contrast with other studies (Marinellie \& Johnson, 2002).

Our results suggest that DLD learners' definitional skills seem to be deviant, rather than delayed, in content, which may imply issues in the full meaning representations of this group (cf. Rice et al., 1995; Mohammadi et al., 2011), at least with abstract and compound words. In addition, the use of more informal definitions may indicate difficulties with word knowledge and organization (cf. McGregor et al., 2013). The similar performance of the two CGs may be justified due to the mean age of the groups that was below the age of ten and, possibly, the learners were not old enough to demonstrate a developmental difference. We should note that older learners in our sample, although they were fewer, used more formal definitions (cf. Caramelli et al., 2006). Therefore, some evidence of decontextualized language use was observed, albeit still limited. A closer look at different word characteristics may provide a clearer picture.

The absence of differences in form may suggest that DLD may exhibit similar developmental patterns than TD learners (cf. Rice et al., 1995; Dosi, 2021). It can also be justified by the majority of the learners in most of the categories using midlevel responses (i.e., verb phrases), in other words, most of the learners preferred to use less complex syntactical structures (cf. Marinellie \& Johnson, 2002).

We should acknowledge that the aforementioned choices may reflect the role of schooling in definitional skills (Schwartz \& Katzir, 2012). The characteristics of definitions are systematically taught in the 5 th and 6th grade of elementary school in Greece, probably leading to better performance of older participants in our 
sample who were found to produce more formal definitions, at least in conceptually less-complex words (i.e., simple words). Given that the instructional method applied in Greece may differ from those of other countries and has an impact on the results reported in this study, future research should focus on Greek-speaking learners and should address the impact of instructional methods on the development of definitional skills by starting with instruction in this regard with younger learners.

\subsection{Effects of word characteristics}

Our second hypothesis also was confirmed partially. All groups more frequently provided low-level responses (i.e., functional definitions) for all words, as found in previous research (Marinellie \& Johnson, 2002; Dosi \& Gavriilidou, 2020). This suggests that school-age learners with and without DLD should not still use decontextualized language (Dosi \& Gavriilidou, 2020). The findings showed that both control groups scored better than the DLD group in terms of content, indicating that the definitional skills of this group were deviant (Meir \& ArmonLotem, 2017; Dosi, 2021). The only exception was found with concrete nouns where the vocabulary-matched group did not differ from the DLD group, which further supports the claim of delayed abilities (cKrzemien et al., 2021). The similar performances of the DLD and CG2 groups might have been due to the characteristics of concrete nouns (Gavriilidou, 2015), which are acquired first, and learners, thus, are more skilled at defining them (Johnson \& Anglin, 1995; Gavriilidou, 2015). The other categories, which are more complex and demanding, may impede full meaning representations in DLD learners (Mohammadi et al., 2011). The finding of no differences between the two CGs may also indicate that TD learners perform at a similar developmental level. An exception is detected in simple words (content and form), where the age-matched group used more formal definitions than the vocabulary-matched group. The different performances of the TD learners may suggest that decontextualized language can be evident only in conceptually simpler words at this age (Johnson \& Anglin, 1995; Gavriilidou, 2015; Dourou, 2019).

Compound words were found to be more challenging and to develop more gradually (Johnson \& Anglin, 1995; Dourou, 2019). More specifically, learners with DLD used tautologies in order to define compound words (Dourou, 2019). The use of tautologies might demonstrate evidence of morpho syntactical and lexical decomposition, but, still, this morphological category is not so well developed in mental lexicon. Despite what was found in previous studies (Grela et al., 2005), we did not observe any disordering of the compounds. In many cases, younger TD learners did not provide a definition of a compound word, which either suggests that they did not know the word, or they did not know how to define it. Compound abstract nouns seemed to be the most difficult to define for all groups. In this category either non-verbal responses were given (i.e., participants gestured or pointed), or most of the vocabulary-matched TD group did not respond at all. These findings suggest that either the word was not known, or if it was, it could not be decontextualized and defined (Dosi \& Gavriilidou, 2020). The finding about compound words provides us with useful information about morphosyntactic abilities (decomposition), and indicates that compound 
words are hard to be decontextualized by school-aged learners, with or without DLD.

In form, as mentioned before, the three groups performed similarly, using midlevel responses (i.e., verb phrases, "something/thing" + referential sentence) or high-level responses (i.e., superordinate category + relative clause) in most of the categories; except age-matched TD learners, who used partially formal definitions in simple concrete and abstract nouns and simple adjectives. This preference for less complex structures may reflect the instructional practices of schooling (Schwartz \& Katzir, 2012).

From these findings, we also deduced that we should examine the interaction of different word characteristics that might affect the development of definitional skills in a different way.

\subsection{Vocabulary use and definitional skills}

Our last hypothesis concerned the link between vocabulary use and definitions. Our expectations were partially confirmed since correlations were attested between vocabulary and overall definitional abilities (in both content and form), scores in nouns (in both content and form) and in adjectives, only in content and only in the age-matched TD learners (Dosi \& Gavriilidou, 2020; Dosi, 2021). Our findings indicate that the link between word-learning (breadth of vocabulary knowledge) and definitions (depth of vocabulary knowledge) is not present from the beginning and it requires time to appear in all grammatical categories (Dosi, 2021). Thus, possibly, it develops earlier with nouns that are conceptually simpler, depend less on the context, are more frequently used, and it is easier to imply their superordinate categories (To et al., 2013), and then in adjectives. In addition, as previous research has shown, knowing a word does not necessarily mean that we can define the word (McGregor et al., 2013). Hence, it conceivably takes time for this link to emerge, since it was not found in learners with DLD and younger TD learners. At the same time, the finding suggests that since the latter two groups performed similarly, it confirms that linguistic abilities of learners with DLD are delayed rather than deviant (Rice et al., 1995; Dosi, 2021).

\section{Conclusions, limitations and further research}

One of the major findings was that definitional skills of DLD learners are rather deviant in content, but not in form, which implies that their abilities are delayed rather than deviant. Another important finding was that definitions of abstract and compound words were more demanding for all learners, which suggests that research and clinical practice should look at the interdependence of different parameters. Finally, breadth of vocabulary correlated with depth of vocabulary in older, typically developing learners; this link, possibly, takes time to emerge in DLD learners.

We should acknowledge some limitations of the study. First and foremost, the cohort of our participants was small ( $n=12$, per group). Nonetheless, it is difficult to find DLD learners without any other developmental disorders in Greece, since these learners are often misdiagnosed. Another limitation concerns the 
intervention, since not all DLD participants in the study received systematic language therapies, nor had they started their language therapies at the same age (Dosi \& Gavriilidou, 2020). Additionally, each therapist applies his/her own intervention method, and this may ensue in a variation of the impact of the intervention (Dosi \& Gavriilidou, 2020).

Finally, though this study is preliminary, it adds value to the existing work on definitional skills by investigating less-researched parameters in the relevant literature in a less-examined language group. We consider our findings less important in terms of firm conclusions, and more groundbreaking as an attempt to steer future research into this direction, in order to add extra, and, thus, more robust data.

\section{Acknowledgments}

Special thanks to the children who participated in this study, their parents who gave their consent and the SLPs for their help and support. We also thank the six anonymous reviewers for their useful and insightful comments for the improvement of the manuscript.

This research is co-financed by Greece and the European Union (European Social Fund- ESF) through the Operational Program «Human Resources Development, Education and Lifelong Learning» in the context of the project "Reinforcement of Postdoctoral Researchers - 2nd Cycle" (MIS-5033021), implemented by the State Scholarships Foundation (IKY).

\section{References}

Bishop, D.V.M. (2017). Why is it so hard to reach agreement on terminology? The case of developmental language disorder (DLD). International Journal of Language $\mathcal{E}$ Communication Disorders, 52, 671-680. https://doi.org/10.1111/1460-6984.12335

Briscoe, J., Bishop, D.V.M. \& Norbury, C.F. (2001). Phonological processing, language, and literacy: A comparison of children with mild to moderate sensorineural hearing loss and those with specific language impairment. The Journal of Child Psychology and Psychiatry and Allied Disciplines, 42(3), 329-340. https:/ / doi.org/10.1111/14697610.00726

Caramelli, N., Borghi, A.M. \& Setti, A. (2006). The identification of definition strategies in children of different ages. Linguistica Computazionale, 26, 155-177.

Conti-Ramsden, G., St Clair, M.C., Pickles, A. \& Durkin, K. (2012). Developmental trajectories of verbal and nonverbal skills in individuals with a history of specific language impairment: From childhood to adolescence. Journal of Speech, Language, and Hearing Research, 55, 1716-1735. https:// doi.org/10.1044/1092-4388(2012/100182).

Dosi, I. (2021). The impact of inhibitory control, working memory and updating on definitional skills of learners with and without Developmental Language Disorder. International Journal of Research Studies in Education, 10(13), 97-107. https://doi.org/10.5861/ijrse.2021.a055

Dosi, I. \& Gavriilidou, Z. (2020). The role of cognitive abilities in the development of definitions by children with and without Developmental Language Disorder. Journal of Psycholinguistic Research, 49(5), 761-777. https://doi.org/10.1007/s10936-020-09711-w

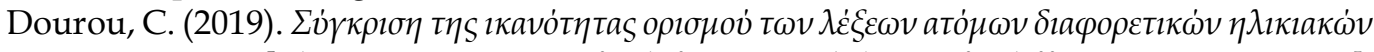
opá $\omega \omega$ [The comparison of definition ability of different age groups]. 
Unpublished doctoral dissertation. Department of Greek Philology. Democritus University of Thrace.

Dourou, C., Gavriilidou, Z. \& Markos, A. (2020). Definitional skills and preferred definition types according to age, gender, educational level and career orientation. International Journal of Research Studies in Education, 9(2), 29-49. https://doi.org/10.5861/ijrse.2020.5021.

Friedmann, N., Aram, D. \& Novogrodsky, R. (2011). Definitions as a window to the acquisition of relative clauses. Applied Psycholinguistics, 32(4), 687-710. https://doi.org/10.1017/S0142716411000026

Gavriilidou, Z. (2015). The development of noun, verb and adjective definitional awareness in Greek preschoolers, Journal of Applied Linguistics, 30, 44-58.

Grela, B., Snyder, W. \& Hiramatsu, K. (2005). The production of novel root compounds in children with specific language impairment. Clinical Linguistics and Phonetics, 19, 701-715. https://doi.org/10.1080/02699200400000368

Gutierrez-Clellen, V., \& DeCurtis, L. (1999). Word definitional skills in Spanish-speaking children with language impairment. Communication Disorders Quarterly, 21(1), 2331. https://doi.org/10.1177/152574019902100104

Johnson, C.J. \& Anglin, J.M. (1995). Qualitative developments in the content and form of children's definitions. Journal of Speech and Hearing Research, 38(3), 612-629. https://doi.org/10.1044/jshr.3803.612

Krzemien, M., Thibaut, J.-P., Jemel, B., Levaux, E. \& Maillart, C. (2021). How do children with developmental language disorder extend novel nouns? Journal of $\begin{array}{llll}\text { Experimental Child } & \text { Psychology, 202, } & 105010 .\end{array}$ https://doi.org/10.1016/j.jecp.2020.105010

Leonard, L.B. (2014). Children with specific language impairments. Cambridge, MA: MIT Press.

Levy, Y. \& Schaeffer, J.C. (Eds). (2003). Language competence across populations: Toward a definition of specific language impairment. Cambridge: University Psychology Press.

McGregor, K.K., Oleson, J., Bahnsen, A. \& Duff, D. (2013). Children with developmental language impairment have vocabulary deficits characterized by limited breadth and depth. International Journal of Language \& Communication Disorders, 48, 307319. https:// doi.org/10.1111/1460-6984.12008

Marinellie, S.A. \& Chan, Y. (2006). The effect of word frequency of noun and verb definitions: A developmental study. Journal of Speech, Language, and Hearing Research, 49(5), 1001-1021. https://doi.org/10.1044/1092-4388(2006/072)

Marinellie, S.A. \& Johnson, C. (2002). Definitional skill in school-age children with specific language impairment. Journal of Communication Disorders, 35(3), 241-259. https://doi.org/10.1016/S0021-9924(02)00056-4

Marinellie, S.A., \& Johnson, C. (2004). Nouns and Verbs: A comparison of definitional style. Journal of Psycholinguistic Research, 33(3), 217-235. https://doi.org/10.1023/B:JOPR.0000027963.80639.88

Meir, N. \& Armon-Lotem, S. (2017). Delay or deviance: Old question-New evidence from bilingual children with specific language impairment (SLI). In LaMendola, M. \& Scott, J. (Eds), Proceedings of the 41st annual Boston University Conference on Language Development (pp. 495-508). Somerville, MA: Cascadilla Press.

Mohammadi, M., Nilipour, R., Shirazi, T.S. \& Rahgozar, M. (2011). Comparison of definitional skills between Persian speaking children with specific language impairment and their age matched normal language developing children. Journal of Rehabilitation, 12(2), 48-55. http://rehabilitationj.uswr.ac.ir/article-1-886en.html

Ponari, M., Norbury, C.F., Rotaru, A., Lenci, A. \& Vigliocco, G. (2018). Learning abstract words and concepts: Insights from developmental language disorder. 
Philosophical Transactions of the Royal Society B: Biological Sciences, 373(1752), 1-9. https://doi.org/10.1098/rstb.2017.0140

Raven, J., Court, J. \& Raven, J.C. (2008). Raven's coloured progressive matrices and vocabulary scales. London: Pearson Education.

Rice, M.L., Wexler, K. \& Cleave, P.L. (1995). Specific language impairment as a period of extended optional infinitive. Journal of Speech and Hearing Research, 38(4), 850-863. https://doi.org/10.1044/jshr.3804.850

Schwartz, M. \& Katzir, T. (2012). Depth of lexical knowledge among bilingual children: The impact of schooling. Reading \& Writing, 25, 1947-1971. https://doi.org/10.1007/s11145-011-9308-9

To, C.K.S., Stokes, S., Man, Y. \& T'sou, B. (2013). An Analysis of Noun Definition in Cantonese. Language and Speech, 56(1), 105-124. https://doi.org/10.1177/0023830912440794

Ullman, M. (2004). Contributions of memory circuits to language: The declarative/procedural model. Cognition, 92, 231-270. https://doi.org/10.1016/j.cognition.2003.10.008

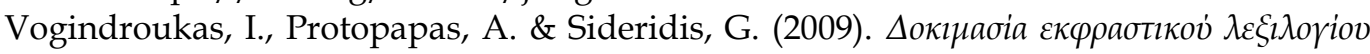
[Expressive vocabulary assessment] (Greek version of Renfrew word finding vocabulary test). Chania, Crete: Glafki. 